\title{
Cigarette butts abundance and association of mercury and lead along the Persian Gulf beach: an initial investigation
}

\author{
Sina Dobaradaran ${ }^{1,2,3}$ • Torsten C. Schmidt ${ }^{4}$ - Iraj Nabipour ${ }^{5}$ • Afshin Ostovar ${ }^{5}$. \\ Alireza Raeisi ${ }^{5}$. Reza Saeedi ${ }^{6}$ - Maryam Khorsand ${ }^{2}$ - Nahid Khajeahmadi ${ }^{2}$. \\ Mozhgan Keshtkar ${ }^{2}$
}

Received: 5 August 2017 / Accepted: 1 November 2017

(C) Springer-Verlag GmbH Germany, part of Springer Nature 2017

\begin{abstract}
The toxic metal contents of cigarette butts and distribution of cigarette butts have not been studied well in maritime environment. In the present study, cigarette butts distribution and the associations of $\mathrm{Hg}$ and $\mathrm{Pb}$ from cigarette butts were monitored along the Persian Gulf with 10 days interval sampling time. The number of cigarette butts, and $\mathrm{Hg}$ and $\mathrm{Pb}$ associations of butts were found to vary widely between 2 and 38 items per square meter, 2.5 and $86.32 \mathrm{ng} / \mathrm{g}$ cigarette butt (CB), as well as 650 and $8630 \mathrm{ng} / \mathrm{g} \mathrm{CB}$, respectively. Wilcoxon signed-rank test showed that there were no significant differences between the number of butts, and $\mathrm{Hg}$ and $\mathrm{Pb}$ contents of the butts at different sampling times. Considering amount of cigarette butts littered yearly, this study demonstrates that remarkable toxic metals of $\mathrm{Hg}$ and $\mathrm{Pb}$ may enter maritime environment each year and may introduce critical hazards to aquatic organisms, enter food chain, and finally human body.
\end{abstract}

Keywords Bushehr $\cdot$ Cigarette butts $\cdot$ Lead $\cdot$ Mercury · Persian Gulf

Responsible editor: Philippe Garrigues

Electronic supplementary material The online version of this article (https://doi.org/10.1007/s11356-017-0676-9) contains supplementary material, which is available to authorized users.

Sina Dobaradaran

sina_dobaradaran@yahoo.com; s.dobaradaran@bpums.ac.ir

1 The Persian Gulf Marine Biotechnology Research Center, The Persian Gulf Biomedical Sciences Research Institute, Bushehr University of Medical Sciences, Boostan 19 Alley, Imam Khomeini Street, Bushehr, Iran

2 Department of Environmental Health Engineering, Faculty of Health, Bushehr University of Medical Sciences, Bushehr, Iran

\section{Introduction}

Cigarette butts are a potential source of contaminants to the marine environment. In region with considerable contents of cigarette waste, ecological hazards may occur, as chemical components are leached from the cigarette butts (Novotny et al. 2009). It is estimated that nearly 4.95 trillion cigarette butts to be wasted every year, worldwide (http://cigwaste.org/ (Cigarette Butt Advisory Group 2009)). Cigarette butts are the single most collected item of whole waste by count during the coastal cleanups worldwide (Novotny et al. 2009; Moore et al. 2001). Beside unsightly, cigarette butt litter may have adverse health effects for humans and animals. Cigarette butts are generally thrown everywhere in environment and public areas such as coastal areas, forests, parks, pavements, roads, and streets where children, pets, and wildlife may be exposed to cigarette butts risks (Novotny et al. 2009). It has been demonstrated that cigarette butts leach out many chemicals such as different toxic metals as well as organic contaminants in water

3 Systems Environmental Health, Oil, Gas and Energy Research Center, The Persian Gulf Biomedical Sciences Research Institute, Bushehr University of Medical Sciences, Bushehr, Iran

4 Instrumental Analytical Chemistry, University Duisburg-Essen, 45141 Essen, Germany

5 The Persian Gulf Tropical Medicine Research Center, The Persian Gulf Biomedical Sciences Research Institute, Bushehr University of Medical Sciences, Bushehr, Iran

6 Department of Health Sciences, School of Health, Safety and Environment, Shahid Beheshti University of Medical Sciences, Tehran, Iran 
and may be a continuous origin for pollution of aquatic environments after throwing away. It was reported that toxicity of cigarette butts in part can be because of toxic metals (Moerman and Potts 2011; Micevska et al. 2006). Although toxic metals in cigarette butts and mainstream smoke have been widely evaluated, limited studies have tried to recognize and quantify the leakage components from cigarette butts. $\mathrm{Hg}$ and $\mathrm{Pb}$ are identified as the highly toxic metals (Mudgal et al. 2010; Liu and Liang 2008). Although Hg is not an abundant chemical element in the environment, it has become widespread due to many industrial applications such as produce batteries, lamp, cement production, electronic and electrical devices, and production of vinyl chloride monomer (Pirrone et al. 2010; Pacyna et al. 2010). Because of its high toxicity and very high bioaccumulation factor (up to 106) in the food chain, the monitoring of $\mathrm{Hg}$ in the marine environment is very crucial (Leopold et al. 2009; Booth and Zeller 2005; Braune et al. 2005). Furthermore, the widespread existence of $\mathrm{Pb}$ in the environment comes from anthropogenic activities. The most significant sources of $\mathrm{Pb}$ exposure are industrial emissions, automobile exhaust gases, soils, and polluted foods (Komárek et al. 2008).

Some studies reported the content levels of $\mathrm{Hg}$ and $\mathrm{Pb}$ in cigarette. Panta et al. (2008) reported Hg content of whole cigarettes, cigars, and chewing tobacco packets as follows: $20.8 \pm 1.0 \mathrm{ng} / \mathrm{g}$ in the cigar, $13.0 \pm 1.3 \mathrm{ng} / \mathrm{g}$ in the cigarettes, and $6.3 \pm 0.6 \mathrm{ng} / \mathrm{g}$ in the chewing tobacco (on fresh weight basis); the cigarette's tobacco and filler accounted for more than $97 \%$ of the $\mathrm{Hg}$ found in the whole cigarette. Kowalski and Wierciński (2009) found $\mathrm{Hg}$ contents of examined cigarette ranged from 2.95 to $10.2 \mathrm{ng}$ per cigarette. Wang et al. (2007) also reported $\mathrm{Hg}$ contents in cigarette filters ranged from 0.002 to $0.051 \mathrm{mg} / \mathrm{kg}$ (Wang et al. 2007). Afridi et al. (2013) found the level of $\mathrm{Pb}$ in filler tobacco of different cigarettes in the range from 0.67 to $1.67 \mu \mathrm{g} / \mathrm{g}$, while Massadeh et al. (2005) reported a range from 2.10 to $3.23 \mu \mathrm{g} / \mathrm{g}$ for the $\mathrm{Pb}$ content of cigarette tobacco.

Due to adverse health and environmental effects of toxic metals including $\mathrm{Hg}$ and $\mathrm{Pb}$, many studies reported the concentration levels of toxic metals in marine environment, marine organisms, and animals in different parts of the world (Table 1). But there is no report yet on $\mathrm{Hg}$ and $\mathrm{Pb}$ contents from cigarette butts in marine environment. So in the present study, we aimed to (1) investigate the number and abundance of cigarette butts per square meter of beaches for the first time in the region of the Persian Gulf and (2) determine the cigarette butts content levels of two notorious toxic metals including $\mathrm{Hg}$ and $\mathrm{Pb}$ along the northern part of the Persian Gulf in the Bushehr seaport coastal area. It should be noted that to the best of our knowledge, the present study is the first study on $\mathrm{Hg}$ and $\mathrm{Pb}$ contents of cigarette butts in marine environment.

\section{Materials and methods}

\section{Study area and sampling}

To determine the quantity of cigarette butts as well as the content levels of $\mathrm{Hg}$ and $\mathrm{Pb}$ with cigarette butts, fields monitoring were carried out at nine stations $\left(\mathrm{S}_{1}-\mathrm{S}_{9}\right)$ in summer 2015. Selected stations were TV park $\left(\mathrm{S}_{1}\right)$, Jofreh $\left(\mathrm{S}_{2}\right)$, Shoghab $\left(\mathrm{S}_{3}\right)$, Rishehr $\left(\mathrm{S}_{4}\right)$, Lian park $\left(\mathrm{S}_{5}\right)$, Bandargah $\left(\mathrm{S}_{6}\right)$, Negin island $\left(\mathrm{S}_{7}\right)$, Abassak island $\left(\mathrm{S}_{8}\right)$, and Shif island $\left(\mathrm{S}_{9}\right)$ along the northern part of the Persian Gulf (Fig. 1). All selected stations have a texture of sand in the surface with grain sizes up to $250 \mu \mathrm{m}$. Sediment samples were collected from top $10 \mathrm{~cm}$ at the intertidal zone (at high tide) on strand from a $1-\mathrm{m}^{3}$ area (volume of sample: $1 \mathrm{~m}^{2} \times 0.1 \mathrm{~m}$ ). First visible cigarette butts were separated from the sediment surface with forceps (with wearing gloves), then the collected sediments were transferred to the laboratory for final separation and enumeration. As there is no any cleanup program in examined areas, to compare the number of cigarette butts as well as $\mathrm{Hg}$ and $\mathrm{Pb}$ content levels at different times, sampling at each beach examined was done two times (second sampling was done in the same place by using Global Positioning System (GPS), Garmin model) with a time interval of 10 days. So in total, a number of 18 sediment samples (two times in every selected station) were collected. Different environmental parameters during sampling days such as average and maximum height of wave, average period of wave, minimum and maximum temperature of seawater, average air temperature, direction of dominant wind, and average speed of wind are shown in supplementary 1 .

\section{Reagent, solutions, and sample preparation}

The utilized reagents were of analytical grade. $\mathrm{HCl}$ and $\mathrm{HNO}_{3}$ applied for the extraction were of supra pure quality (Merck, Germany). All glassware and plastic were cleaned by soaking in dilute $\mathrm{HNO}_{3}(10 \%(w / v))$ and washed with distilled water before use. All solutions were prepared using ultrapure water (resistivity $18.2 \mu \Omega \mathrm{cm}$ ).

\section{Metal analysis}

Cigarette butts from each beach examined were selected without considering the amounts of adherent substances. First, adherent substance was manually removed from the beached cigarette butts by using a small cleaning brush. Then, $\mathrm{Hg}$ and $\mathrm{Pb}$ were extracted from cigarette butts by using a modified aqua regia extraction. Aqua regia was prepared by mixing 3 $\mathrm{M} \mathrm{HNO}_{3}$ and $2 \mathrm{M} \mathrm{HCl}$ in a ratio of 1:3 (Ashton et al. 2010). Weighed cigarette butts from every examined beach were separately added to polypropylene centrifuge tubes, and $20 \mathrm{ml}$ of aqua regia was added; afterwards, the tubes were shaken at 
Table 1 The concentration levels of $\mathrm{Pb}$ and $\mathrm{Hg}$ in marine environment, marine organisms, and animals in different parts of the world

\begin{tabular}{|c|c|c|c|c|}
\hline Sampling sites & Sample type & $\mathrm{Pb}$ content & $\mathrm{Hg}$ content & References \\
\hline South-west Anatolia, Turkey & Fish/tissues of Leucis cephalus & $0.068-0.874 \mu \mathrm{g} / \mathrm{g}$ & - & Yilmaz et al. 2007 \\
\hline South-west Anatolia, Turkey & $\begin{array}{l}\text { Fish/tissues of Lepomis } \\
\text { gibbosus }\end{array}$ & $0.070-0.920 \mu \mathrm{g} / \mathrm{g}$ & & Yilmaz et al. 2007 \\
\hline $\begin{array}{l}\text { Urban streams of Semarang, } \\
\text { Indonesia }\end{array}$ & Fish/guppy, Poecilia reticulate & $\begin{array}{l}\text { Polluted station, } 6.9 \\
\quad \pm 7.7 \mu \mathrm{g} / \mathrm{g} \\
\text { Non-polluted station, } \\
0.8 \pm 0.7 \mu \mathrm{g} / \mathrm{g}\end{array}$ & - & $\begin{array}{l}\text { Widianarko et al. } \\
2000\end{array}$ \\
\hline $\begin{array}{l}\text { Elechi creek in Port Harcourt, } \\
\text { Nigeria }\end{array}$ & $\begin{array}{l}\text { Fish species/tissues of } \\
\text { Sarontheron } \\
\text { melanotheron }\end{array}$ & $2.3 \pm 0.13 \mathrm{mg} / \mathrm{kg}$ & - & $\begin{array}{r}\text { Vincent-Akpu and } \\
\text { Babatunde } 2013\end{array}$ \\
\hline $\begin{array}{l}\text { River Orogodo (Agbor, } \\
\text { Delta State, Nigeria) }\end{array}$ & Sediment & $0.3-0.96 \mathrm{mg} / \mathrm{kg}$ & - & Issa et al. 2011 \\
\hline $\begin{array}{l}\text { Ria de Vigo, funnel-shaped, } \\
\text { fault-bounded coastal } \\
\text { embayment in Galicia, } \\
\text { NW Spain }\end{array}$ & Sediment & $160.1 \pm 1.2 \mathrm{mg} / \mathrm{kg}$ & - & Rubio et al. 2000 \\
\hline Jade Bay in NW Germany & Sediment & $16 \pm 10 \mu \mathrm{g} / \mathrm{g}$ & - & Beck et al. 2013 \\
\hline SW England & Foams & $111 \mu \mathrm{g} / \mathrm{g}$ & - & Turner 2016 \\
\hline $\begin{array}{l}\text { Northern coast of Qeshm } \\
\text { Island, Persian Gulf, Iran }\end{array}$ & $\begin{array}{l}\text { Oysters/tissue and shell of } \\
\text { Saccostrea cucullata }\end{array}$ & $\begin{array}{l}\text { Soft tissue, } \\
\quad 10.74 \mu \mathrm{g} / \mathrm{g} \\
\text { Shell, } 26.06 \mu \mathrm{g} / \mathrm{g}\end{array}$ & - & $\begin{array}{l}\text { Shirneshan and } \\
\text { Riyahi Bakhtiari } \\
2012\end{array}$ \\
\hline $\begin{array}{l}\text { Lengeh Port, Qeshm and } \\
\text { Hormoz Islands in } \\
\text { Persian Gulf, Iran }\end{array}$ & $\begin{array}{l}\text { Sediment and shell of rocky } \\
\text { oysters (Saccostrea } \\
\text { cucullata) }\end{array}$ & $\begin{array}{l}\text { Sediment, } \\
0.86-180.78 \mu \mathrm{g} / \mathrm{g} \\
\text { Shell, } \\
0.06-613.94 \mu \mathrm{g} / \mathrm{g}\end{array}$ & - & Kazemi et al. 2013 \\
\hline $\begin{array}{l}\text { Alaro stream ecosystem of } \\
\text { south-west Nigeria }\end{array}$ & $\begin{array}{l}\text { (Mollusca: } \\
\text { thiaridae)/freshwater snail } \\
\text { Melanoides tuberculata }\end{array}$ & $10.12-14.12 \mathrm{ppm}$ & - & $\begin{array}{l}\text { Tyokumbur and } \\
\text { Okorie } 2014\end{array}$ \\
\hline $\begin{array}{l}\text { Mediterranean marina, Port } \\
\text { Camargue, France }\end{array}$ & Sediment & Up to $94 \mu \mathrm{g} / \mathrm{g}$ & Up to $0.82 \mu \mathrm{g} / \mathrm{g}$ & Briant et al. 2010 \\
\hline $\begin{array}{l}\text { Brown Bay (Beagle Channel), } \\
\text { Ushuaia, Tierra del Fuego, } \\
\text { Argentina }\end{array}$ & $\begin{array}{l}\text { Mussels/Mytilus edulis } \\
\text { chilensis } \\
\text { and sediment }\end{array}$ & $\begin{array}{l}\text { Sediment, } \\
10.19-28.76 \mu \mathrm{g} / \mathrm{g} \\
\text { Gill and digestive } \\
\text { gland, } \\
\text { 3.37-15.57 } \mu \mathrm{g} / \mathrm{g}\end{array}$ & - & $\begin{array}{l}\text { Giarratano et al. } \\
\quad 2010\end{array}$ \\
\hline $\begin{array}{l}\text { Eastern part of the Johore } \\
\text { Straits, Malaysia }\end{array}$ & $\begin{array}{l}\text { Green-lipped mussel/soft tis- } \\
\text { sues } \\
\text { of Perna viridis }\end{array}$ & $\begin{array}{l}\text { Foot, } 11.4 \\
\quad \pm 1.49 \mu \mathrm{g} / \mathrm{g} \\
\text { Gill, } 14.2 \\
\quad \pm 11.9 \mu \mathrm{g} / \mathrm{g} \\
\text { Muscle, } 11.0 \\
\quad \pm 4.20 \mu \mathrm{g} / \mathrm{g}\end{array}$ & J & Yap et al. 2012 \\
\hline Scotland, Great Britain & $\begin{array}{l}\text { Mammals/common porpoise } \\
\text { (Phocoena phocoena) }\end{array}$ & & $\begin{array}{l}\text { Liver: mean levels for } \\
\text { females were } 6.03 \mathrm{mg} / \mathrm{kg} \\
\text { and for males } 3.42 \mathrm{mg} / \mathrm{kg}\end{array}$ & Falconer et al. 1983 \\
\hline Ontario lakes, Canada & $\begin{array}{l}\text { Fishes/walleye (Stizostedion } \\
\text { vitreum vitreum) and } \\
\text { northern pike (Esox lucius) }\end{array}$ & - & $\begin{array}{l}\text { Walleye: } \\
\text { Stizostedion vitreum } \\
\text { vitreum, } 0.65 \mu \mathrm{g} / \mathrm{g} \\
\text { Northern pike: Esox lucius, } \\
0.52 \mu \mathrm{g} / \mathrm{g}\end{array}$ & Wren et al. 1991 \\
\hline $\begin{array}{l}\text { Welsh coast and the Irish Sea, } \\
\text { Scotland }\end{array}$ & $\begin{array}{l}\text { Marine mammals/striped } \\
\text { dolphin Stenella } \\
\text { coeruleoalba }\end{array}$ & $\begin{array}{l}\text { Liver: mean levels } \\
0.05-7.0 \mu \mathrm{g} / \mathrm{g}\end{array}$ & $\begin{array}{l}\text { Liver: mean levels } \\
0.5-280 \mu \mathrm{g} / \mathrm{g}\end{array}$ & Law et al. 1992 \\
\hline $\begin{array}{l}\text { Uppanar estuary, southeast } \\
\text { coast of India }\end{array}$ & $\begin{array}{l}\text { Molluscs: } \\
\text { Meretrix meretrix, } \\
\text { Crassostrea madrasensis } \\
\text { Cerithidea cingulate }\end{array}$ & $\begin{array}{l}\text { M. meretrix tissue, } \\
0.278 \pm 0.01 \mathrm{ppm} \\
\text { M. meretrix shell, } \\
0.083 \pm 0.01 \mathrm{ppm} \\
\text { C. madrasensis } \\
\text { tissue, } 0.285 \\
\pm 0.01 \mathrm{ppm} \\
\text { C. madrasensis shell, } \\
0.034 \pm 0.01 \mathrm{ppm} \\
\text { C. cingulate tissue, } \\
0.072 \pm 0.01 \mathrm{ppm} \\
\text { C. cingulate shell, } \\
0.070 \pm 0.01 \mathrm{ppm}\end{array}$ & - & Kesavan et al. 2013 \\
\hline
\end{tabular}


Table 1 (continued)

\begin{tabular}{|c|c|c|c|}
\hline Sampling sites & Sample type & $\mathrm{Hg}$ content & References \\
\hline $\begin{array}{l}\text { Ada and Aveglo at the Volta estuary, } \\
\text { Ghana (March to September, 2008) }\end{array}$ & $\begin{array}{l}\text { Clam/tissue of the clam } \\
\text { Galatea paradoxa }\end{array}$ & $\begin{array}{l}\text { Ada: } \\
\text { Small-sized clams, } \\
0.028-0.049 \mu \mathrm{g} / \mathrm{g} \\
\text { Medium-sized clams, } \\
0.035-0.049 \mu \mathrm{g} / \mathrm{g} \\
\text { Large-sized clams, } \\
0.044-0.059 \mu \mathrm{g} / \mathrm{g} \\
\text { Aveglo: } \\
\text { Small-sized clams, } \\
\text { 0.037-0.055 } \mathrm{g} / \mathrm{g} \\
\text { Medium-sized clams, } \\
\text { 0.042-0.056 } \mu \mathrm{g} / \mathrm{g} \\
\text { Large-sized clams, } \\
0.037-0.074 \mu \mathrm{g} / \mathrm{g}\end{array}$ & $\begin{array}{l}\text { Adjei-Boateng } \\
\quad \text { et al. } 2010\end{array}$ \\
\hline $\begin{array}{l}\text { Clear Water Bay, Kowloon, Hong } \\
\text { Kong }\end{array}$ & $\begin{array}{l}\text { Five species of marine bivalves: } \\
\text { Scallops, Chlamys nobilis } \\
\text { Clams, Ruditapes philippinaru } \\
\text { Oysters, Saccostrea cucullata } \\
\text { Green mussels, Perna viridis } \\
\text { Black mussels, Septifer virgatus }\end{array}$ & $\begin{array}{l}\text { Scallops: } \\
\text { C. nobilis, } 60.3 \pm 14.2 \mathrm{ng} / \mathrm{g} \\
\text { Clams: } \\
\text { R. philippinaru, } 30.2 \\
\quad \pm 4.1 \mathrm{ng} / \mathrm{g} \\
\text { Oysters: } \\
\text { S. cucullata, } 47.4 \\
\quad \pm 15.3 \mathrm{ng} / \mathrm{g} \\
\text { Green mussels: } \\
\text { P. viridis, } 70.3 \pm 15.3 \mathrm{ng} / \mathrm{g} \\
\text { Black mussels: } \\
\text { S. virgatus, } 91.9 \\
\quad \pm 18.8 \mathrm{ng} / \mathrm{g}\end{array}$ & $\begin{array}{l}\text { Pan and Wang } \\
2011\end{array}$ \\
\hline
\end{tabular}

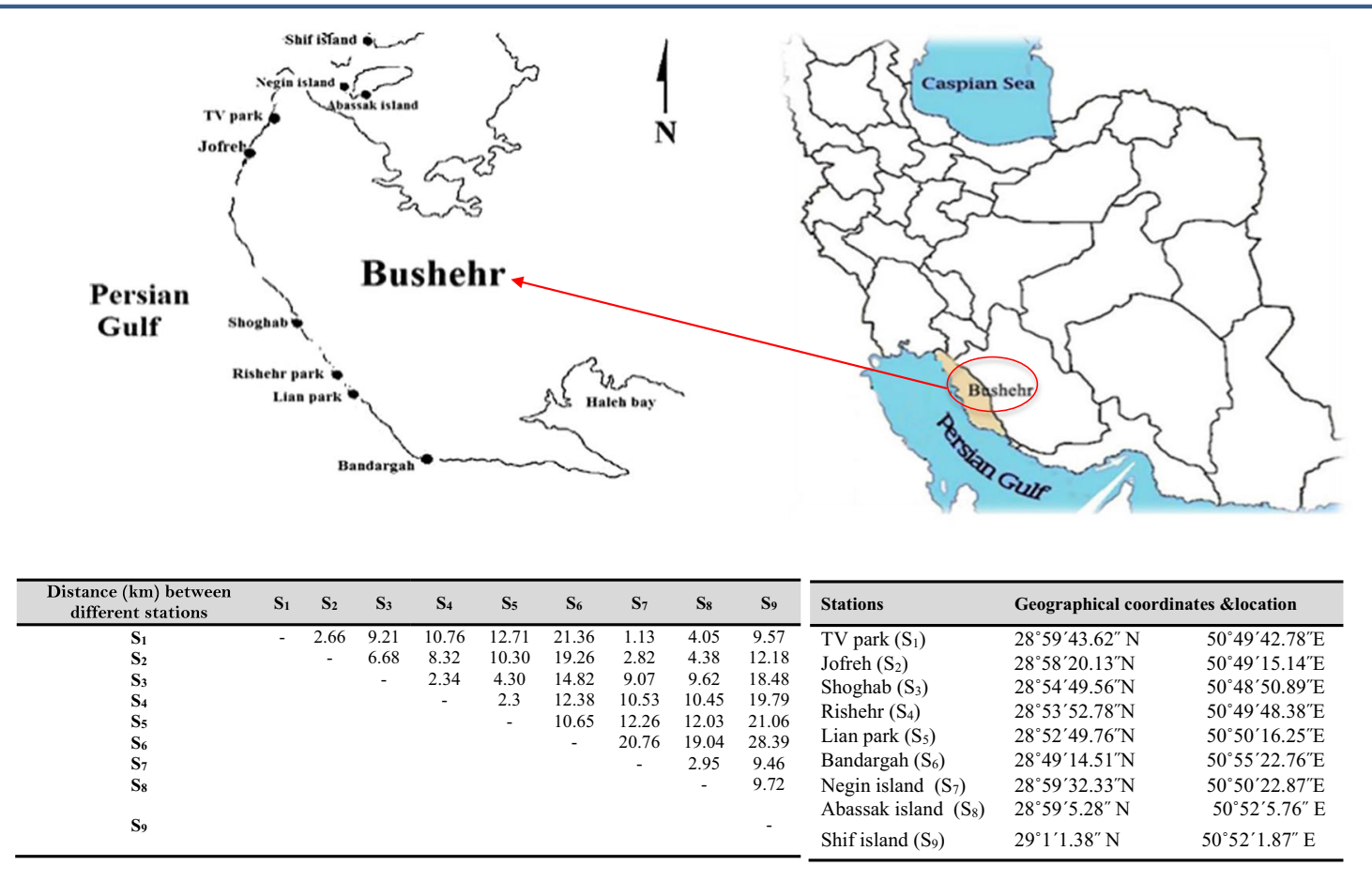

Fig. 1 Geographic coordinates and location of sampling stations along the Persian Gulf 
$100 \mathrm{rpm}$ for $24 \mathrm{~h}$. Then, the contents were filtered by pouring into a 50 volumetric flask through a Whatman filter paper (pore size, $2.5 \mu \mathrm{m}$ ). The same bulk preparation of aqua regia was used all over extraction for all blanks and calibration to ensure consistency in the analysis of extraction. The filtered samples were analyzed for the contents of $\mathrm{Hg}$ and $\mathrm{Pb}$ by using a cold vapor and graphite furnace atomic absorption spectrophotometer (Varian AA240, USA). Every sample was measured three times, and the mean value is reported here. The limit of detection (LOD) and the limit of quantification (LOQ) were calculated as 3 and $10 \mathrm{sd} / \mathrm{m}$, respectively. Where sd is the standard deviation for ten measurements of the calibration blank, and $\mathrm{m}$ is the slope of the calibration curve. The measured LOD and LOQ values were calculated per mass of cigarette butts. These values for $\mathrm{Hg}$ were $9.1 \times 10^{-4} \mu \mathrm{g} / \mathrm{mg}$ and $2.1 \times 10^{-3} \mu \mathrm{g} / \mathrm{mg}$, respectively. The values obtained for $\mathrm{Pb}$ were $9.8 \times 10^{-4} \mu \mathrm{g} / \mathrm{mg}$ (LOD) and $2.28 \times 10^{-3} \mu \mathrm{g} / \mathrm{mg}$ (LOQ).

\section{Statistical analysis}

Statistical analysis of data was performed with the statistical package for the social sciences (SPSS, Version 21). To see the effect of the current sea, the Wilcoxon signed-rank test was used for statistical significant differences between the number of cigarette butts, and $\mathrm{Hg}$ and $\mathrm{Pb}$ contents of cigarette butts at different sampling times. The Spearman correlation coefficient test was also used to analyze any significant relationship between environmental parameters shown in supplementary 1 and the number of cigarette butts, and $\mathrm{Hg}$ and $\mathrm{Pb}$ contents of cigarette butts. Differences in mean values were accepted as being significant if $p<0.05$.

\section{Results and discussion}

The number of cigarette butts, and $\mathrm{Hg}$ and $\mathrm{Pb}$ contents of the cigarette butts along the northern part of the Persian Gulf in the Bushehr seaport coastal area, as measured, is shown in Fig. 2a-c. The number of cigarette butts, and $\mathrm{Hg}$ and $\mathrm{Pb}$ contents of cigarette butts was found to vary widely between 2 and 38 items per square meter, 2.5 and $86.32 \mathrm{ng} / \mathrm{g}$ cigarette butt (CB), and 650 and $8630 \mathrm{ng} / \mathrm{g} \mathrm{CB}$, respectively. The Wilcoxon signed-rank test showed that there were no significant differences between the number of cigarette butts, and $\mathrm{Hg}$ and $\mathrm{Pb}$ contents of the cigarette butts at different sampling times along the urban coastal area. The mean numbers of cigarette butts were 10.78 and 9.33 items per square meter at the first day and after 10 days of sampling times, respectively. The Spearman correlation coefficient analysis also demonstrated that there were no significant correlations between the number of cigarette butts, and $\mathrm{Hg}$ and $\mathrm{Pb}$ contents of the cigarette butts with environmental parameters (including average and maximum height of wave, average period of wave,
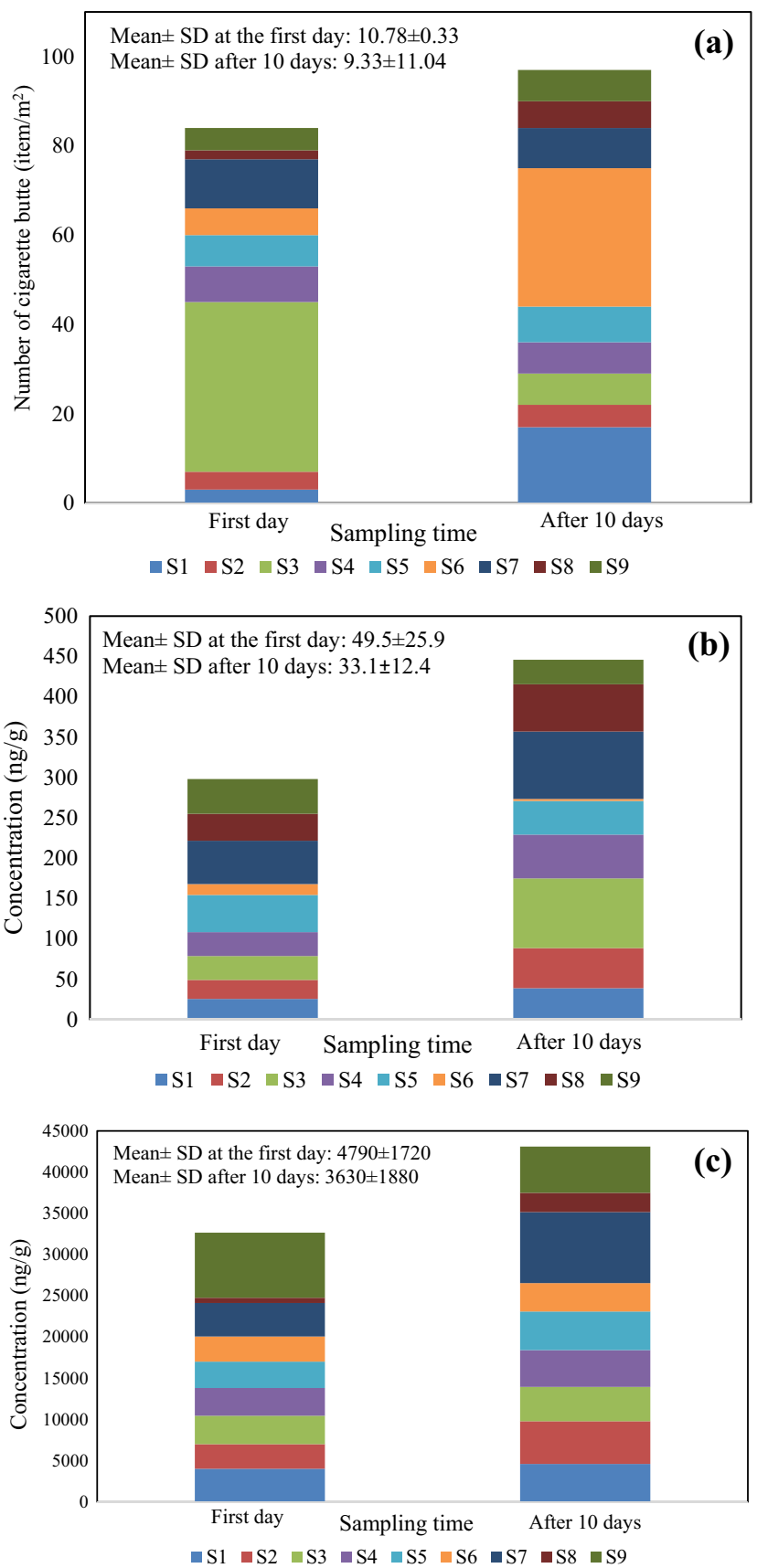

Fig. 2 Number of cigarette butts (a) and associations of $\mathrm{Hg}(\mathbf{b})$ and $\mathrm{Pb}(\mathbf{c})$ with cigarette butts

minimum and maximum temperature of seawater, average air temperature, direction of dominant wind, and average speed of wind) shown in supplementary 1 . This can be due to low differences in the most mentioned environmental parameters during the sampling times. But it seems further studies are necessary to discover these correlations. Especially comparative studies in different areas with diffident environmental parameters such as direction of dominant speed, average speed of wave, and height of wave are highly recommended. Cigarette butts are the most common form of litter in the world 
(Novotny et al. 2009), and they were found to be a major source of coastline accumulation of debris (Hoellein et al. 2014). Collected cigarette butts per unit of area in former studies from other regions of the world are compared with the present study in Table 2. As seen in Table 2, most of reported data on cigarette butt numbers per unit of area are in the urban areas. But measured numbers of cigarette butts in our study compare to marine environment/Armação dos Búzios, Brazil (Oigman-Pszczol and Creed 2007) are quite high and showed that the northern part of the Persian Gulf in the Bushehr seaport coastal area is heavily polluted.

Even higher number compare to our result was also reported in the urban beaches in the eastern coast of Mallorca (Balearic Islands). Beach-goers, direct throw by smokers, and water channeled by open sewer systems (there is no storm water collection system in Bushehr and storm water flow directly by channel to the Persian Gulf) appear to be the major potential sources of cigarette butts along the urban shorelines in Bushehr. However, some of these cigarette butts may also be transported from other urban areas by wind or storm water and finally end up on the coasts. Cigarette butts on beaches may be accessed by children, sea creatures, birds, and even pets. There are some reports on accidental ingestion of cigarette butts in children especially those $<6$ years old (Smolinske et al. 1988; Malizia et al. 1983; Bonadio and Anderson 1989; Mcgee et al. 1995; Kubo and Chishiro 2008; Centers for Disease Control and Prevention (CDC)1997; Quirk 2009; Bronstein et al. 2012), and in some cases, severe toxicity have been seen. Also, there is a report on cigarette butts ingestion by sea turtles (Stanley et al. 1988). It should be noted even there are no well-documented reports on cigarette butts ingestion by wildlife, but it does not mean such ingestion does not happen.

The mean values of $\mathrm{Hg}$ contents of cigarette butts were 49.5 and $33.1 \mathrm{ng} / \mathrm{g} \mathrm{CB}$ at the first day and after 10 days of sampling times, respectively. The mean values of $\mathrm{Pb}$ content of cigarette butts were 4790 and $3630 \mathrm{ng} / \mathrm{g} \mathrm{CB}$ at the first day and after 10 days of sampling times, respectively. The toxic metals leached from cigarette butts have been identified and quantified by only a few studies, and except a study (Dobaradaran et al. 2017), these studies were not in marine environments. It should be noted that except a recent study by Dobaradaran et al. (2017) on content levels of Cd, Fe, As, $\mathrm{Ni}, \mathrm{Cu}, \mathrm{Zn}$, and $\mathrm{Mn}$ with cigarette butts, there are no studies so far on toxic metal and especially $\mathrm{Hg}$ and $\mathrm{Cd}$ contents of cigarette butts in marine environments and coastline areas. They reported that $\mathrm{Cd}, \mathrm{Fe}, \mathrm{As}, \mathrm{Ni}, \mathrm{Cu}, \mathrm{Zn}$, and $\mathrm{Mn}$ contents of cigarette butts were found to vary widely between 0.16 and $0.67 \mu \mathrm{g} / \mathrm{g}, 79.01$ and $244.97 \mu \mathrm{g} / \mathrm{g}, 0.12$ and $0.48 \mu \mathrm{g} / \mathrm{g}, 1.13$ and $3.27 \mu \mathrm{g} / \mathrm{g}, 4.29$ and $12.29 \mu \mathrm{g} / \mathrm{g}, 6.39$ and $21.17 \mu \mathrm{g} / \mathrm{g}$, and 38.29 and $123.1 \mu \mathrm{g} / \mathrm{g}$, respectively. They found that there were no significant differences between $\mathrm{Cd}, \mathrm{Fe}, \mathrm{As}, \mathrm{Ni}, \mathrm{Cu}, \mathrm{Zn}$, and $\mathrm{Mn}$ contents of the cigarette butts at different sampling times and concluded notable metals may enter the marine environment annually. In a study, Moriwaki et al. (2009) determined the concentration levels of $\mathrm{Pb}(0.72 \mathrm{mg} / \mathrm{g}), \mathrm{Cr}$ $(0.18 \mathrm{mg} / \mathrm{g}), \mathrm{Cd}(0.024 \mathrm{mg} / \mathrm{g})$, and $\mathrm{Cu}(2.1 \mathrm{mg} / \mathrm{g})$ in cigarette butts collected from waste on roadside. In another study, Moerman and Potts measured the contents of $\mathrm{Al}, \mathrm{Cd}, \mathrm{Pb}, \mathrm{Cr}$, $\mathrm{Ni}, \mathrm{Ba}, \mathrm{Fe}, \mathrm{Cu}, \mathrm{Sr}, \mathrm{Zn}, \mathrm{Mn}$, and Ti leached from cigarette butts collected from container adjacent to building on the university campus as well as unsmoked cigarette. With the exception of $\mathrm{Cd}$, they found all metals in leachates at different rates 1 day after sample addition. They reported that there was no clear correlation between $\mathrm{pH}$ values of aqueous soaking solution and leached metal levels. They also reported that the concentration level of $\mathrm{Pb}$ ranged from 1.12 to $1.42 \mu \mathrm{g} / \mathrm{g}$ after different periods of soaking from 1 to 34 days. Finally, they concluded that cigarette litter can be a point source of metal contamination, and metal leachates from cigarette butts may enhance the risk of acute damage to local organisms (Moerman and Potts 2011). The reported leached levels of $\mathrm{Pb}, \mathrm{Cd}, \mathrm{Cr}$, and $\mathrm{Cu}$ in Moriwaki et al. (2009) study were two to seven times more than the levels in Moerman and Potts study. Moerman and Potts (2011) said that these differences are due to difference in leaching methods used. So, further studies are required to establish a standard leaching method for metals detection from cigarette butts.
Table 2 Collected cigarette butts in different regions around the world and compare with present study

\begin{tabular}{|c|c|c|}
\hline Location of sample collection & Number/density of cigarette butts & Reference \\
\hline $\begin{array}{l}\text { Marine environment/Armação dos } \\
\text { Búzios, Brazil }\end{array}$ & $\begin{array}{l}\text { Mean butts density, } 0.1376 \text { items } / \mathrm{m}^{2} \\
\quad\left(13.76 \text { items } / 100 \mathrm{~m}^{2}\right)\end{array}$ & Quirk 2009 \\
\hline Typical suburb in Japan (Ueda city) & $\begin{array}{l}0.00015 \mathrm{items} / \mathrm{m}^{2} / \text { month (mean) } \\
\left(150 \text { items } / \mathrm{km}^{2} / \text { month) }\right.\end{array}$ & Moriwaki et al. 2009 \\
\hline $\begin{array}{l}\text { Urban beach/eastern coast of } \\
\text { Mallorca/Balearic Islands }\end{array}$ & $\begin{array}{l}\text { Mean butts } 36 \text { items } / \mathrm{m}^{2} \\
\quad \text { (max: up to } 68 \text { items } / \mathrm{m}^{2} \text { ) }\end{array}$ & Martinez-Ribes et al. 2007 \\
\hline $\begin{array}{l}\text { Urban environment/San Diego, } \\
\text { California }\end{array}$ & $\begin{array}{l}\text { Mean butts } 38.1 \text { items } / \mathrm{m}^{2} \\
\quad \text { (range } 11-77)\end{array}$ & Marah and Novotny 2011 \\
\hline Urban waters/Berlin, Germany & 2.7 items $/ \mathrm{m}^{2}$ (average concentration) & Green et al. 2014 \\
\hline $\begin{array}{l}\text { The present study (northern } \\
\text { part of the Persian Gulf) }\end{array}$ & Between 2 and 38 items $/ \mathrm{m}^{2}$ & - \\
\hline
\end{tabular}


Cigarette filters are made of cellulose acetate and may act similar to other plastics in transporting of metals in marine environments. In a study, Ashton et al. determined the concentration levels of metals including $\mathrm{Pb}, \mathrm{Ag}, \mathrm{Cd}$, $\mathrm{Cr}, \mathrm{Co}, \mathrm{Fe}, \mathrm{Cu}, \mathrm{Mn}, \mathrm{Zn}, \mathrm{Al}, \mathrm{Mo}, \mathrm{Sb}, \mathrm{Sn}, \mathrm{U}$ but not $\mathrm{Hg}$ with plastic production pellets in the marine environment. They concluded that plastic fragments (micro- and macro-) accumulate and transport metals in the marine environment and can be used as metal pollution indicators. Metals on plastic materials are adsorbed to the surface of plastic materials or connected with biogenic or hydrogenous phases, and can take place in a relatively bioaccessible form to fauna that ingest them by mistake (Ashton et al. 2010). In another study, interactions between metals with plastic production pellets under estuarine conditions were studied (Holmes et al. 2014). It was found that adsorption of metals including $\mathrm{Pb}, \mathrm{Cd}, \mathrm{Cr}, \mathrm{Co}, \mathrm{Ni}$, and $\mathrm{Cu}$ was much greater in beached pellets than to virgin pellets, likely due to the weathering of and adsorption and abrasion of charged minerals by the former components. Holmes et al. (2012) also monitored adsorption of $\mathrm{Cd}, \mathrm{Pb}, \mathrm{Ni}, \mathrm{Cr}, \mathrm{Cu}$, $\mathrm{Co}$, and $\mathrm{Zn}$ to plastic resin pellets in the marine environment and found that plastics may indicate a major vehicle for metals transport in the marine environment.

In a study, it was shown that the $\mathrm{Hg}$ content in the filter was higher after than before smoking the cigarette for most examined cigarette brands (Kowalski and Wierciński 2009), and this can highlight that cigarette litter and cigarette butts may also be a main diffuse source for metal contamination in marine environments after throwing away. There is a big question regarding metals leaching from cigarette butts in marine environments. Cigarette butts may release metals by leaching, but at the same time, they may concentrate metals from aquatic environments. It was reported that if leaching occur in a closed system, maybe dynamic equilibrium happen between aqueous soaking solution and the cigarette butts (Moerman and Potts 2011), but in aquatic environments, water replacement occurs surrounding the cigarette butts in a rate that exceeds that of equilibrium. The obvious leaching of metals enhances the risk of acute damage to local species (Moerman and Potts 2011). It was suggested that the toxicity of cigarette butt leachates is in part due to trace and toxic metals (Micevska et al. 2006). In a study in 2011, it was found that the toxicity of cigarette butt leachates increased from unsmoked cigarette filters (no tobacco) to smoked cigarette filters (no tobacco) to smoked cigarette butts (smoked filter + tobacco). The researchers affirmed the toxicity of cigarette butts to fish and some other representative marine organisms, representative marine bacteria, and daphnids (Slaughter et al. 2011). In another study by Register on freshwater cladoceran Daphnia magna, it was found that 48-h LC50 values of smoked cigarette tobacco, smoked cigarette filter, and unsmoked cigarette filter leachates were 0.125 and $0.25,1$ and 2 , and $>16$ cigarette butts/l, respectively. All mentioned leachates were acutely toxic to Daphnia magna (Register 2000). Micevska et al. (2006) also reported that leachates from different brands of smoked butts were toxic to Ceriodaphnia cf. dubia as well as Vibrio fischeri with 48h EC50 (immobilization) value of $0.03-0.08$ butts $/ 1$ and 30min EC50 (bioluminescence) value of 0.3-2.7 butts/1, respectively. Lastly, Warne et al. (2002) reported acute toxic effects of smoked cigarette butts, smoked cigarette filters, and unsmoked cigarette butts leachates to the freshwater cladoceran Ceriodaphnia cf. dubia at 0.06, 0.16, and 1.7 butts/1 (48-h EC50 (immobilization)), respectively (Warne et al. 2002). Also, in the case of Vibrio fischeri, they reported 30-min EC50 (bioluminescence) values of $0.58,1.25$, and $>970$ butts/1 for smoked cigarette butts, smoked cigarette filters, and unsmoked cigarette butts leachates, respectively. These results can assist researchers in assessing the potential ecological risks of cigarette butts to marine environments in further studies. Therefore, considering the estimated number of cigarette butts littered annually (4.95 trillion), the results of this study indicate that considerable toxic metals of $\mathrm{Hg}$ and $\mathrm{Pb}$ may enter marine environments and coastline areas each year from cigarette litter and finally reach aquatic food chain and adversely affect marine environment and organisms as well as human health via different ways.

\section{Conclusion}

The present study is one of a limited number of studies that reports metals associations with cigarette butts and the first study that report $\mathrm{Hg}$ and $\mathrm{Pb}$ leached in the marine environment. In this study, cigarette butts abundance as well as the content levels of $\mathrm{Hg}$ and $\mathrm{Pb}$ with cigarette butts were monitored along the northern part of the Persian Gulf. The results of this study confirmed the abundance of cigarette butts in marine environment and suggest that littered cigarette butts are major sources for prolonged metals contamination such as $\mathrm{Hg}$ and $\mathrm{Pb}$ in coastline area. Considering the different response of organisms to metals in former studies, more research is necessary to comprehensively understand the leaching behavior of toxic metals from cigarette butts in marine environment. Further studies are highly necessary to answer all scientific questions that exist on this topic such as the release of all other toxic compounds from cigarette butts to aquatic ecosystems, the effects on environmental quality and ecological risks, chemical toxicity of cigarette butt leachates on water and aquatic organisms, the diffusion pathway in the marine environment, and leachates from cigarette butts after their biodegradation. Finally, the results of this study can be helpful for policy makers find effective solutions to prevent hazards that may introduce by cigarette butts to marine environments, aquatic organisms, and human health. 
Acknowledgments The authors are thankful to the Bushehr University of Medical Sciences for their financial and technical support to the present study as well as the laboratory staff of the Environmental Health Engineering Department for their cooperation. This project was partly supported by Iran National Science Foundation (Research Chair Award No. 95/INSF/44913).

Funding This work was supported by the Bushehr University of Medical Sciences [grant numbers 9197].

\section{References}

Adjei-Boateng D, Obirikorang KA, Amisah S (2010) Bioaccumulation of heavy metals in the tissue of the clam Galatea paradoxa and sediments from the Volta Estuary. Ghana Int J Environ Resour Res 4: $533-540$

Afridi HI, Kazi TG, Talpur FN, Brabazon D, Naher S (2013) Estimation of toxic elements in the samples of different cigarettes and their impact on human health of Irish hypertensive consumers. Clin Chim Acta 426:51-57

Ashton K, Holmes L, Turner A (2010) Association of metals with plastic production pellets in the marine environment. Mar Pollut Bull 60: 2050-2055

Beck M, Böning P, Schückel U, Stiehl T, Schnetger B, Rullkötter J, Brumsack H (2013) Consistent assessment of trace metal contamination in surface sediments and suspended particulate matter: a case study from the Jade Bay in NW Germany. Mar Pollut Bull 70:100-111

Bonadio WA, Anderson Y (1989) Tobacco ingestions in children. Clin Ped 28:592

Booth S, Zeller D (2005) Mercury, food webs, and marine mammals: implications of diet and climate change for human health. Environ Health Perspect 113:521-526

Braune BM, Outridge PM, Fisk AT, Muir DCG, Helm PA, Hobbs K, Hoekstra PF, Kuzyk ZA, Kwan M, Letcher RJ, Lockhart WL, Norstrom RJ, Stern GA, Stirling I (2005) Persistent organic pollutants and mercury in marine biota of the Canadian Arctic: an overview of spatial and temporal trends. Sci Total Environ:351-352

Briant N, Bancon-Montigny C, Elbaz-Poulichet F, Freydier R, Delpoux S, Cossa D (2010) Trace elements in the sediments of a large Mediterranean marina (Port Camargue, France): levels and contamination history. Mar Pollut Bull 73:78-85

Bronstein AC, Spyker DA, Cantilena LR Jr, Rumack BH, Dart RC (2012) 2011 annual report of the American Association of Poison Control Centers' National Poison data system (NPDS): 29th annual report, 911-1164

Centers for Disease Control and Prevention (CDC) (1997) Ingestion of cigarettes and cigarette butts by children - Rhode Island, January 1994-July 1996. MMWR Morb Mortal Wkly Rep 46:125-128

Cigarette Butt Advisory Group (2009) How many filtered cigarettes are deposited into the environment each year? California, 2009. http:// cigwaste.org/

Dobaradaran S, Nabipour I, Saeedi R, Ostovar A, Khorsand M, Khajeahmadi N, Hayati R, Keshtkar M (2017) Association of metals $(\mathrm{Cd}, \mathrm{Fe}, \mathrm{As}, \mathrm{Ni}, \mathrm{Cu}, \mathrm{Zn}$ and $\mathrm{Mn}$ ) with cigarette butts in northern part of the Persian Gulf. Tob Control 26:461-463

Falconer CR, Davies IM, Topping G (1983) Trace metals in the common porpoise, Phocoena phocoena. Mar Environ Res 8:119-127

Giarratano E, Duarte CA, Amin OA (2010) Biomarkers and heavy metal bioaccumulation in mussels transplanted to coastal waters of the Beagle Channel. Ecotoxicol Environ Saf 73:270-279

Green ALR, Putschew A, Nehls T (2014) Littered cigarette butts as a source of nicotine in urban waters. J Hydrol 519:3466-3474
Hoellein T, Rojas M, Pink A, Gasior J, Kelly J (2014) Anthropogenic litter in urban freshwater ecosystems: distribution and microbial interactions. PLoS One 9(6):e98485

Holmes LA, Turner A, Thompson RC (2012) Adsorption of trace metals to plastic resin pellets in the marine environment. Environ Pollut $160: 42-48$

Holmes LA, Turner A, Thompson RC (2014) Interactions between trace metals and plastic production pellets under estuarine conditions. Mar Chem 167:25-32

Issa BR, Arimoro FO, Ibrahim M, Birma GJ, Fadairo EA (2011) Assessment of sediment contamination by heavy metals in River Orogodo (Agbor, Delta State, Nigeria). Curr World Environ 6:29-38

Kazemi A, Riyahi Bakhtiari A, Kheirabadi N, Mohammad Karimi A (2013) Distribution of Pb in Sediment and shell of Rocky Oysters (Saccostrea cucullata) of Lengeh Port, Qeshm and Hormoz Islands in Persian Gulf. Iran ECOPERSIA 1:191-198

Kesavan K, Murugan A, Venkatesan V, Kumar V (2013) Heavy metal accumulation in molluscs and sediment from Uppanar estuary, southeast coast of India. Thalassas 29:15-21

Komárek M, Ettler V, Chrastný V, Mihaljevič M (2008) Lead isotopes in environmental sciences: a review. Environ Int 34(4):562-577

Kowalski R, Wierciński J (2009) Mercury content in smoke and tobacco from selected cigarette brands. Ecol Chem Eng S 16:155-162

Kubo K, Chishiro T (2008) Six-year review of cigarette ingestion in children - gastric lavage versus medical observation[Abstract]. Chudoku kenkyu 21:115-122

Law RJ, Jones BR, Baker JR, Kennedy S, Milne R, Morris RJ (1992) Trace metals in the livers of marine mammals from the Welsh coast and the Irish Sea. Mar Pollut Bull 24:296-304

Leopold K, Foulkes M, Worsfold PJ (2009) Preconcentration techniques for the determination of mercury species in natural waters. Trends Analyt Chem 28:426-435

Liu R, Liang P (2008) Determination of trace lead in water samples by graphite furnace atomic absorption spectrometry after preconcentration with nanometer titanium dioxide immobilized on silica gel. J Hazard Mater 152:166-171

Malizia E, Andreucci G, Alfani F, Smeriglio M, Nicholai P (1983) Acute intoxication with nicotine alkaloids and cannabinoids in children from ingestion of cigarettes. Hum Toxicol 2:315-316

Marah M, Novotny TE (2011) Geographic patterns of cigarette butt waste in the urban environment. Tob Control 20(Suppl 1):i42-i44

Martinez-Ribes L, Basterretxea G, Palmer M, Tintoré J (2007) Origin and abundance of beach debris in the Balearic Islands. Sci Mar 71:305-314

Massadeh AM, Alali FQ, Jaradat QM (2005) Determination of cadmium and lead in different cigarette brands in Jordan. Environ Monit Assess 104:163-170

Mcgee D, Brabson T, Mccarthy J, Picciotti M (1995) Four-year review of cigarette ingestions in children. Pediatr Emerg Care 11:13-16

Micevska T, Warne MSJ, Pablo F, Patra R (2006) Variation in, and causes of, toxicity of cigarette butts to a cladoceran and microtox. Arch Environ Contam Toxicol 50:205-212

Moerman J, Potts G (2011) Analysis of metals leached from smoked cigarette litter. Tob Control 20:i30-i35

Moore SL, Gregorio D, Carreon M, Weisberg SB, Leecaster MK (2001) Composition and distribution of beach debris in Orange County, California. Mar Pollut Bull 42:241-245

Moriwaki H, Kitajima S, Katahira K (2009) Waste on the roadside, 'poisute'waste: its distribution and elution potential of pollutants into environment. Waste Manag 29:1192-1197

Mudgal V, Madaan N, Mudgal A, Singh RB, Mishra S (2010) Effect of toxic metals on human health. Open Nutraceuticals J 3:94-99

Novotny TE, Lum K, Smith E, Wang V, Barnes R (2009) Cigarettes butts and the case for an environmental policy on hazardous cigarette waste. Int J Environ Res Public Health 6:1691-1705 
Oigman-Pszczol SS, Creed JC (2007) Quantification and classification of marine litter on beaches along Armação dos Búzios, Rio de Janeiro, Brazil. J Coast Res:421-428

Pacyna EG, Pacyna JM, Sundseth K, Munthe J, Kindbom K, Wilson S, Steenhuisen F, Maxson P (2010) Global emission of mercury to the atmosphere from anthropogenic sources in 2005 and projections to 2020. Atmos Environ 44:2487-2499

Pan K, Wang WX (2011) Mercury accumulation in marine bivalves: influences of biodynamics and feeding niche. Environ Pollut 159: 2500-2506

Panta YM, Qian S, Cross CL, Cizdziel JV (2008) Mercury content of whole cigarettes, cigars and chewing tobacco packets using pyrolysis atomic absorption spectrometry with gold amalgamation. J Anal Appl Pyrolysis 83:7-11

Pirrone N, Cinnirella S, Feng X, Finkelman RB, Friedli HR, Leaner J, Mason R, Mukherjee AB, Stracher GB, Streets DG, Telmer K (2010) Global mercury emissions to the atmosphere from anthropogenic and natural sources. Atmos Chem Phys 10:5951-5964

Quirk JT (2009) Cigarette-related injuries to young children in the USA, 2002-2007. Public Health 123:628-629

Register K (2000) Cigarette butts as litter- toxic as well as ugly? Underw Nat 25:23-29

Rubio B, Nombela MA, Vilas F (2000) Geochemistry of major and trace elements in sediments of the Ria De Vigo (NW Spain): an assessment of metal pollution. Mar Pollut Bull 40:968-980

Shirneshan G, Riyahi Bakhtiari A (2012) Accumulation and distribution of $\mathrm{Cd}, \mathrm{Cu}, \mathrm{Pb}$ and $\mathrm{Zn}$ in the soft tissue and shell of oysters collected from the northern coast of Qeshm Island, Persian Gulf. Iran Chem Speciat Bioavailab 24:129-138

Slaughter E, Gersberg RM, Watanabe K, Rudolph J, Stransky C, Novotny TE (2011) Toxicity of cigarette butts, and their chemical components, to marine and freshwater fish. Tob Control 20:i25-i29

Smolinske SC, Spoerke DG, Spiller SK, Wruk KM, Kulig K, Rumackt BH (1988) Cigarette and nicotine chewing gum toxicity in children. Hum Exp Toxicol 7:27-31
Stanley KM, Stabenau EK, Landry AM (1988) Debris ingestion by sea turtles along the Texas coast, In Eighth Annual Workshop on Sea Turtle Conservation and Biology. Fort Fisher, NC, USA: NOAA Technical. Memorandum:119-121

Turner A (2016) Heavy metals, metalloids and other hazardous elements in marine plastic litter. Mar Pollut Bull 111:136-142

Tyokumbur ET, Okorie TG (2014) Bioconcentration of trace metals in the freshwater snail Melanoides tuberculata (Mollusca: Thiaridae) from Alaro stream ecosystem of South West Nigeria. Adv Biosci Bioeng 2(1)

Vincent-Akpu IF, Babatunde BB (2013) Trace metals in water, fish and sediments from Elechi Creek, Port Harcourt, Rivers State, Nigeria. Trop Freshw Biol 22:13

Wang Y, Yao X-Y, Li D, Jin X, Li Q-C, Sun B, Han Y-H, Fan L, Qi Q-P (2007) Determination of hg and as in cigarette filter components with hydride generation-atomic fluorescence spectrometry. Tob Sci Technol 9:41-45

Warne MSJ, Patra RW, Cole B, Lunau B (2002) Toxicity and a hazard assessment of cigarette butts to aquatic organisms. Interact 2002 Programme and Abstract Book. Sydney, Australia 1:21-25

Widianarko B, Van Gestel CAM, Verweij RA, Van Straalen NM (2000) Associations between trace metals in sediment, water, and guppy, Poecilia reticulata (Peters), from urban streams of Semarang, Indonesia. Ecotoxicol Environ Saf 46:101-107

Wren CD, Scheider WA, Wales DL, Muncaster BW, Gray IM (1991) Relation between mercury concentrations in walleye (Stizostedion vitreum vitreum) and northern pike (Esox lucius) in Ontario lakes and influence of environmental factors. Can J Fish Aquat Sci 48: 132-139

Yap CK, Sulaiman M, Edward FB, Tan SG (2012) Anthropogenic inputs of heavy metals in the east part of the Johore Straits as revealed by their concentrations in the different soft tissues of Perna viridis (L). Pertanika J Trop Agric Sci 35:815-822

Yılmaz F, Özdemir N, Demirak A, Tuna AL (2007) Heavy metal levels in two fish species Leuciscus cephalus and Lepomis gibbosus. Food Chem 100:830-835 